\title{
Risk analysis and strategic planning on bridge construction works at the toll road procurement projects in Central Java Province
}

\author{
Hery Suliantoro ${ }^{1, *}$, Nurul Fitriani ${ }^{2}$ and Bagus Hario Setiadji ${ }^{2}$ \\ ${ }^{1}$ Industrial Engineering, Diponegoro University, Semarang Indonesia \\ ${ }^{2}$ Civil Engineering, Diponegoro University, Semarang Indonesia
}

\begin{abstract}
Risk is a condition caused by uncertainty. Risks will occur on any construction project, including bridge construction projects. Efforts that can be taken to minimize the impact of these risks are to engage in risk management activities. This research was conducted on bridge construction work on toll road procurement project in Pejagan-Pemalang, Pemalang-Batang and Salatiga-Kertasura. The purpose of this research is to analyze the risk of bridge development project in toll road project using Risk Breakdown Structure (RBS) method and then the result as database in discussing risk response strategy. The bridge construction project has 36 risks that are divided into six groups: materials and equipment, design, human resources, finance, management, nature and environmental conditions. Bad weather risks are the higest risk and seasonal risk causing temporary work stoppages. This risk-response strategy is avoidance. Shortterm avoidance response strategy is to add shift workers, install tents and add additives in the acceleration of the process of maturation of concrete. The long-term avoidance response strategy is to evaluate and rearrange the work schedule by considering the weather forecast report.
\end{abstract}

\section{Introduction}

Some Toll Road Projects in Central Java Province which are parts of Mega Trans Java Project (Cikampek West Java - Gempol East Java along $652 \mathrm{Km}$ ) are still under construction. Among them are the Pejagan-Pemalang, Pemalang-Batang and SalatigaKertasura Road Projects. In those projects, there are bridge projects whose existence is quite essential; therefore it needs maximum handling efforts, including risk mitigation. Risk is a consequence of uncertain conditions in a project. There is a correlation between risk and the quality of construction project implementation [1].

Risks in bridge construction projects may include financial risk, external risk, design risk, management risk, construction risk, contractual risk, and health and safety risks [2]. Mitigation of risk can be carried out by conducting risk management plans. A risk management plan is considered as an attempt of analyzing risks that can enrich the decision-making process and provide additional arguments to help choosing the optimal

\footnotetext{
*Corresponding author: suliantoro hery@yahoo.com
} 
variant using multiple approaches [3]. Nevertheless, the risk management policies should be implemented and evaluated regularly to minimize the probability of failure [4].

This study aims to analyze the risks in the bridge construction project at the toll road project. In the analysis conducted will be known the risks that influence, value, category, and mitigation of each risk.

\section{Literatur Review}

\subsection{Risk Management}

The risks in the construction project are irreversible, but their impacts can be minimized [5]. An effort which can be done to minimize the impact is to carry out risk management activities [2]. International Standard (2009) [6] describes 5 (five) stages of risk management process: (1) Establish the context; This shows the relationship between the problem and the organization environment, the risk management process and the standard risk criteria, (2) Risk Identification; The identification process includes: what risks, when, where, how and why risks can occur, (3) Risk Analysis; Determine how much impact and possible risks will occur. Then the level of each risk is determined, (4) Risk Evaluation; Risk evaluation is carried out by comparing the estimated risk level against predetermined criteria and (5) Risk Treatment; Risk treatment is the stage of development and implementation of strategies and action plans for the selection of the best response.

\subsection{Risk Breakdown Structure Method (RBS)}

RBS is an aid for identifying, assessing, comparing, and reporting risk. A long list of risks can be hard to structure and prioritize, therefore the RBS can be a more effective tool to breaking down the risks and helping the project manager focus attention on certain risks. According to Hillson [7], RBS results risk response planning that will be useful as future project guideline.

RBS is a hierarchical structure of the source of risk, the method of grouping project risk based on the source that can organize and define the overall risk faced by a project. In general, RBS will be divided into 4 (four) levels, namely: References to printed journal articles should typically contain: Level 0 states a risky program, Level 1 is a global grouping such as a bridge construction project risk, Level 2 is a category of level 1 in the form of grouping of several risks such as planning risk group, risk contract group, operational risk group and so on, and Level 3 is a more specific risk description according to level 2.

\section{Reseach Methods}

The object of this research is the bridge project in the Pejagan-Pemalang Toll Road Project (17 bridges), Pemalang-Batang (27 bridges), and Salatiga-Kertasura (12 bridges).

Data collection method used in this research is observation and communication. Observation method used to get secondary data that is by searching data needed in book, journal, and other publication related to research theme. While communication method used to get primary data that is through interview and filling questioner.

Data collection begins with collecting secondary data to identify the initial risks which are then used as a reference for obtaining primary data through interviews and filling in questionnaires. Secondary data were taken using the observation method to obtain / identify the initial risks which were then used as reference in obtaining the primary data. Primary 
data is taken using the method of communication through interviews and filling questionnaires distributed in 2 (two) stages. Questionnaire I is a risk validation effort, questionnaire II is an effort to assess the frequency and impact level.

This research uses purposive sampling technique that is sample determination technique with certain considerations, so there is no limitation related to the number of samples. Respondents in this study are stakeholders that include contractors and supervisory consultants. Questionnaire I, respondents are experts / experts who have at least 5 years experience working on construction projects. While Questionnaire II, respondents are technical staff from contractors and supervisory consultants. Data analysis performed include nonparametric test, validity test, reliability test and risk analysis with Risk Breakdown Structure (RBS) method.

The purpose of this study was to explore the risk factors on the bridge project. This research is exploratory research. In this study, the factors affecting the bridge construction project are explored in depth. After obtaining the research factors with exploratory research, then these factors become the basis in preparing the questionnaire which is then analyzed to know the impact and its management. The method of analysis used is Risk Breakdown Structure (RBS). Hillson [7], states that RBS is a hierarchical structure of risk sources that can define the overall risk faced by a project. After the risk hierarchy is formulated then proceed with determining the value of the frequency level as a reference in categorizing and ranking each risk.

The variables in this study are risk factors derived from several references that are then validated using communication methods that is through questionnaires and interviews. The variables in this study can be seen in Table 1 .

Table 1. The Exploration of Risk Factor

\begin{tabular}{|c|c|c|}
\hline No. & Risk Factors & Reference \\
\hline & Materials and Equipment & \\
\hline 1 & Material Shortage & Asmarantaka, $2014[8]$ \\
\hline 2 & Material Error on form, function and specification & Asmarantaka, $2014[8]$ \\
\hline 3 & Delay of Material Supply & Asmarantaka, 2014 [8] \\
\hline 4 & Material Damage in Storage & Asmarantaka, 2014 [8] \\
\hline 5 & Material Scarcity & Asmarantaka, $2014[8]$ \\
\hline 6 & Inaccurate timing of material order & Asmarantaka, 2014 [8] \\
\hline 7 & Delay of Equipment & Research Proposal \\
\hline 8 & Equipment Damage & Winaktu et al., 2014 [9] \\
\hline 9 & Equipment Shortage & Asmarantaka, $2014[8]$ \\
\hline \multirow[t]{2}{*}{10} & Equipment Productivity & Asmarantaka, $2014[8]$ \\
\hline & Design & \\
\hline 11 & Design Changes & Vidivelli et al., $2017[10]$ \\
\hline 12 & Design Variation & Zou et al., $2006[11]$ \\
\hline 13 & Error in Design by Planner & Asmarantaka, $2014[8]$ \\
\hline 14 & Error in drawing/specification & Taufik, $2010[1]$ \\
\hline \multirow[t]{2}{*}{15} & $\begin{array}{l}\text { Unclear information on the scope of work at the time } \\
\text { of job description }\end{array}$ & Taufik, $2010[1]$ \\
\hline & Human Resource & \\
\hline 16 & Less professional & Zou et al., 2006 [11] \\
\hline 17 & Less labor & Zou et al., 2006 [11] \\
\hline 18 & Low labor ability & Asmarantaka, $2014[8]$ \\
\hline 19 & Low labor productivity & Choudhry and Aslam, \\
\hline
\end{tabular}




\begin{tabular}{|c|c|c|}
\hline No. & Risk Factors & Reference \\
\hline & & $2011[2]$ \\
\hline & Finance & \\
\hline 20 & Inflation & $\begin{array}{l}\text { Choudhry and Aslam, } \\
2011[2]\end{array}$ \\
\hline 21 & Financial Failure of the Contractor & $\begin{array}{l}\text { Choudhry and Aslam, } \\
2011[2]\end{array}$ \\
\hline 22 & Poor Estimation of Unexpected Cost & Research Proposal \\
\hline 23 & Incomplete Cost Estimation & Zou et al., 2006 [11] \\
\hline 24 & Unrealistic Cost estimation & Vidivelli et al., 2017 [10] \\
\hline \multirow[t]{2}{*}{25} & Late Payment & Vidivelli et al., 2017 [10] \\
\hline & Management & \\
\hline 26 & Error in Understanding Contract Document & Asmarantaka, 2014 [8] \\
\hline 27 & Document is incomplete & Zou et al., $2006[11]$ \\
\hline 28 & Less coordination & Vidivelli et al., 2017 [10] \\
\hline 29 & Dispute & Zou et al., $2006[11]$ \\
\hline 30 & $\begin{array}{l}\text { Inadequate project information (soil test and survey } \\
\text { report) }\end{array}$ & Zou et al., 2006 [11] \\
\hline 31 & Error in choosing implementation method & Asmarantaka, 2014 [8] \\
\hline 32 & Strict project schedule & Zou et al., $2006[11]$ \\
\hline 33 & Poor program scheduling & Zou et al., $2006[11]$ \\
\hline 34 & Delay during construction process & Vidivelli et al., 2017 [10] \\
\hline 35 & Many work errors require rework & Research Proposal \\
\hline 36 & Job implementation does not follow SOP & Asmarantaka, $2014[8]$ \\
\hline 37 & Bad K3 management & Asmarantaka, 2014 [8] \\
\hline 38 & Poor surveillance and site management & $\begin{array}{l}\text { Choudhry and Aslam, } \\
2011 \text { [2] }\end{array}$ \\
\hline \multirow[t]{2}{*}{39} & Subcontractor failure & $\begin{array}{l}\text { Choudhry and Aslam, } \\
2011 \text { [2] }\end{array}$ \\
\hline & $\begin{array}{l}\text { Nature and Environment } \\
\text { Conditions }\end{array}$ & \\
\hline 40 & Earthquake & Winaktu et al., 2014 [9] \\
\hline 41 & Landslide & Winaktu et al., 2014 [9] \\
\hline 42 & Bad weather & Asmarantaka, $2014[8]$ \\
\hline 43 & Late permissions & Asmarantaka, 2014 [8] \\
\hline 44 & A less secure project development environment & Asmarantaka, 2014 [8] \\
\hline 45 & Disagreement interests with citizens & Research Proposal \\
\hline 46 & Unstable government policy & $\begin{array}{l}\text { Choudhry and Aslam, } \\
2011 \text { [2] }\end{array}$ \\
\hline 47 & Excessive government approval procedures & Zou et al., 2006 [11] \\
\hline
\end{tabular}

Risk Probability and Impact Assessment is investigating the possibility of occurrence of some specific risks and the potential effects (negative impacts as well as positive impacts) of a project that may affect the project's ultimate objectives such as time, quality, price, scope of work. A commonly used analytical method is Probability and Impact Matrix, where risk can be arranged on a priority scale for the next step of quantitative analysis and risk mitigation.

Evaluation of the importance of each risk, as well as the priority of attention to risks can typically use Table 2. In this table the organization can determine anywhere from a combination of probabilities of risks and the effects of those riks in the classification of 
high risk, medium risk and low risk. The probability level values consist of values of 0.1 to 0.9 and an impact level value comprising values of 0.05 to 0.8 . The probability and impact of the advantages and disadvantages can be analyzed in one matrix, by defining the good from each of the risks from different levels [12].

Table 2. Probability and Impact Matrix

\begin{tabular}{|c|c|c|c|c|c|c|c|c|c|c|}
\hline \multicolumn{11}{|c|}{ Probability and Impact Matrix } \\
\hline \multirow{2}{*}{$\begin{array}{c}\text { Probability } \\
0.90\end{array}$} & \multicolumn{5}{|c|}{ Threats } & \multicolumn{5}{|c|}{ Opportunities } \\
\hline & 0.05 & 0.09 & 0.18 & 0.36 & 0.72 & 0.72 & 0.36 & 0.18 & 0.09 & 0.05 \\
\hline 0.70 & 0.04 & 0.07 & 0.14 & 0.28 & 0.56 & 0.56 & 0.28 & 0.14 & 0.07 & 0.04 \\
\hline 0.50 & 0.03 & 0.05 & 0.10 & 0.20 & 0.40 & 0.40 & 0.20 & 0.10 & 0.05 & 0.03 \\
\hline 0.30 & 0.02 & 0.03 & 0.06 & 0.12 & 0.24 & 0.24 & 0.12 & 0.06 & 0.03 & 0.02 \\
\hline \multirow[t]{2}{*}{0.10} & 0.01 & 0.01 & 0.02 & 0.04 & 0.08 & 0.08 & 0.04 & 0.02 & 0.01 & 0.01 \\
\hline & $\begin{array}{l}0.05 / \\
\text { Very Low }\end{array}$ & $\begin{array}{c}0.10 / \\
\text { Low }\end{array}$ & $\begin{array}{c}0.20 / \\
\text { Moderate }\end{array}$ & $\begin{array}{c}0.40 / \\
\text { High }\end{array}$ & $\begin{array}{l}0.80 / \\
\text { Very High }\end{array}$ & $\begin{array}{c}0.80 / \\
\text { Very High }\end{array}$ & $\begin{array}{l}0.40 / \\
\text { High }\end{array}$ & $\begin{array}{l}0.20 / \\
\text { Moderate }\end{array}$ & $\begin{array}{c}0.10 / \\
\text { Low }\end{array}$ & $\begin{array}{l}0.05 / \\
\text { Very Low }\end{array}$ \\
\hline \multicolumn{11}{|c|}{ Impact (numerical scale) on an objective (e.g., cost, time, scope or quality) } \\
\hline
\end{tabular}

Quantitative Risk Analysis is a risk analysis based on the risk priority resulting from qualitative analysis. In this method, the risk is analyzed to find out how much effect will be generated by giving a number that indicates the level of risk. The quantitative analysis is to assess the importance of risk to know which risks are most influential to the bridge construction project. The equation for calculating the value of risk level can be seen in equation 1 .

\section{Level of risk interest $=$ Probability $x$ Impact}

This quantitative analysis should be performed again after the Risk Response Planning phase, as part of the Risk Monitoring and Control.

Nonparametric test was conducted to know the level of difference of understanding based on respondent data. The test was performed with the help of SPSS program in the form of testing two samples using Mann Whitney U Test. Validity test is a test used to indicate how accurately the instrument is used. While the reliability test is a test to determine the extent to which the consistency of the instrument used. The validity test is used to find out if there are any questions in the invalid questionnaire that should be discarded. While the reliability test is used to determine whether the instruments in the study can produce consistent data. The testing technique for validity test using SPSS software is by looking at the value of corrected item-total correlation. Testing technique for reliability test also use SPSS software by looking at coefficient value of alpha cronbach.

Once the ranking and risk categories are identified, then an analysis of the causes, impacts and respon of each of the risks can be done. Analysis of causes, impacts and risk management was obtained by conducting interviews with three experts. Risk response planning is a process of developing options and determining the most effective actions so that it is expected to increase the opportunity and reduce the risk seen from the negative 
side of the challenge. The type of response to risk is divided into four, there are : (1) avoid; the project team acts to eliminate risks or protect the project from its impact, (2) transfer; the project team transfers the impact of risk to a third party, (3) mitigate; the project team acts to reduce the likelihood of occurrence or impact of a risk, (4) accept; the project team decides to recognize the risks and does not take any action unless such risk occurs.

\section{Result and Discussion}

The analysis begins with identifying risk, followed by validity and reliability test. Data which is valid and reliable is continued to next analysis stage. Risks which affect the bridge construction project can be seen in Table 3 .

Table 3. Risk Identification in Risk Breakdown Structure

\begin{tabular}{|c|c|c|c|c|c|c|}
\hline Level 0 & & Level 1 & & Level 2 & & Level 3 \\
\hline \multirow{25}{*}{ 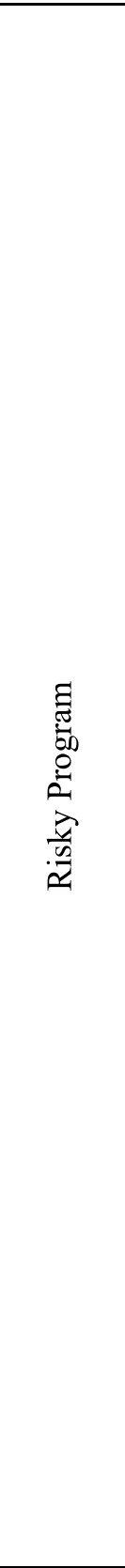 } & \multirow[t]{25}{*}{ A } & \multirow{25}{*}{ 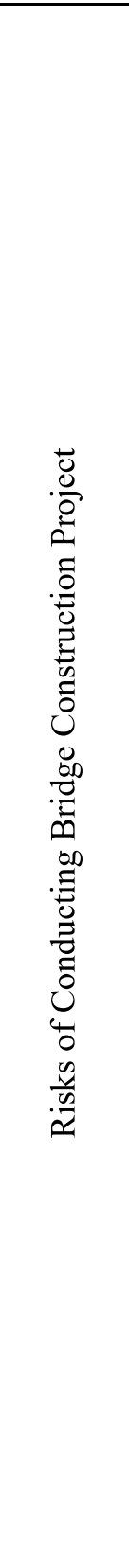 } & \multirow[t]{9}{*}{1} & \multirow{9}{*}{$\begin{array}{l}\text { Materials and } \\
\text { Equipment }\end{array}$} & $\mathrm{X} 1$ & Material Shortage \\
\hline & & & & & $\mathrm{X} 2$ & $\begin{array}{l}\text { Material Error on form, function and } \\
\text { specification }\end{array}$ \\
\hline & & & & & $\mathrm{X} 3$ & Delay of Material Supply \\
\hline & & & & & $\mathrm{X} 4$ & Material Damage in Storage \\
\hline & & & & & $\mathrm{X} 5$ & Material Scarcity \\
\hline & & & & & X6 & Inaccurate timing of material order \\
\hline & & & & & $\mathrm{X} 7$ & Delay of Equipment \\
\hline & & & & & $\mathrm{X} 8$ & Equipment Damage \\
\hline & & & & & X9 & Equipment Shortage \\
\hline & & & \multirow[t]{2}{*}{2} & \multirow[t]{2}{*}{ Design } & $\mathrm{X} 10$ & Error in Design by Planner \\
\hline & & & & & $\mathrm{X} 11$ & Design Changes \\
\hline & & & \multirow[t]{3}{*}{3} & \multirow{3}{*}{$\begin{array}{l}\text { Human } \\
\text { Resource }\end{array}$} & $\mathrm{X} 12$ & Less professional \\
\hline & & & & & $\mathrm{X} 13$ & Less labor \\
\hline & & & & & $\mathrm{X} 14$ & Low labor ability \\
\hline & & & \multirow[t]{5}{*}{4} & \multirow[t]{5}{*}{ Finance } & $\mathrm{X} 15$ & Inflation \\
\hline & & & & & $\mathrm{X} 16$ & Financial Failure of the Contractor \\
\hline & & & & & $\mathrm{X} 17$ & Poor Estimation of Unexpected Cost \\
\hline & & & & & $\mathrm{X} 18$ & Incomplete Cost Estimation \\
\hline & & & & & X19 & Late Payment \\
\hline & & & \multirow[t]{6}{*}{5} & \multirow[t]{6}{*}{ Management } & $\mathrm{X} 20$ & $\begin{array}{l}\text { Error in Understanding Contract } \\
\text { Document }\end{array}$ \\
\hline & & & & & $\mathrm{X} 21$ & Document is incomplete \\
\hline & & & & & $\mathrm{X} 22$ & Less coordination \\
\hline & & & & & $\mathrm{X} 23$ & Dispute \\
\hline & & & & & $\mathrm{X} 24$ & $\begin{array}{l}\text { Inadequate project information (soil test } \\
\text { and survey report) }\end{array}$ \\
\hline & & & & & $\mathrm{X} 25$ & Error in choosing implementation method \\
\hline
\end{tabular}




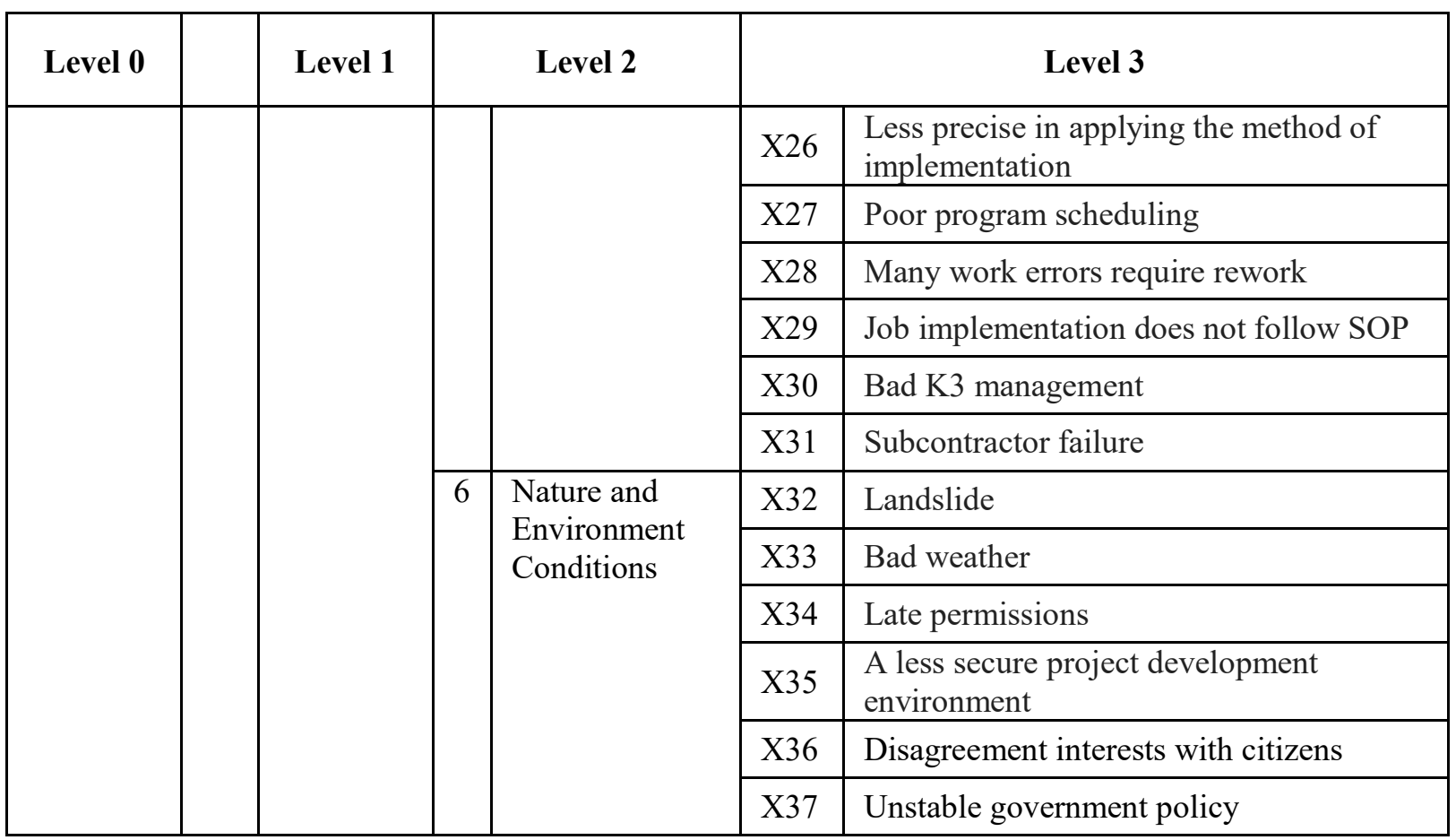

Validity test is performed on the frequency and impact of risk with corrected item-total correlation technique by comparing the $r$ value of SPSS and $r$ table (37 variables is 0.324 ). The variable declared invalid as the value of $r$ arithmetic $<r$ table is a design change with the value of $r$ count frequency of 0.312 . Reliability test performed on frequency and impact of risk with alpha cronbach technique. Based on the analysis that has been done, the instrument is stated reliable if the value of alpha cronbach $>0.6$.

Recapitulation of respondent's answer to frequency and impact is analyzed and reciprocated to obtain value of risk level. Based on these values determined the category and handling strategies required.

Table 4. The Value of Frequency, Impact, Level of Interest, Category, and Strategy of Handling

\begin{tabular}{|c|l|c|c|c|c|c|}
\hline Variable & \multicolumn{1}{|c|}{ Risks } & $\begin{array}{c}\text { Frequency } \\
\text { (a) }\end{array}$ & $\begin{array}{c}\text { Impact } \\
\text { (b) }\end{array}$ & $\begin{array}{c}\text { Level of } \\
\text { Risk } \\
\text { Interest } \\
\text { (axb) }\end{array}$ & $\begin{array}{c}\text { Risk } \\
\text { Category }\end{array}$ & $\begin{array}{c}\text { Risk } \\
\text { Handling } \\
\text { Strategy }\end{array}$ \\
\hline \multicolumn{7}{|l|}{ Material and Equipment } \\
\hline X1 & Material Shortage & 0,346 & 0,231 & 0,080 & Medium & Mitigation \\
\hline X2 & $\begin{array}{l}\text { Material Error on form, } \\
\text { function and } \\
\text { specification }\end{array}$ & 0,263 & 0,222 & 0,058 & Low & Monitoring \\
\hline X3 & Delay of Material Supply & 0,392 & 0,208 & 0,082 & Medium & Mitigation \\
\hline X4 & $\begin{array}{l}\text { Material Damage in } \\
\text { Storage }\end{array}$ & 0,346 & 0,216 & 0,075 & Medium & Mitigation \\
\hline X5 & Material Scarcity & 0,292 & 0,206 & 0,060 & Medium & Mitigation \\
\hline X6 & $\begin{array}{l}\text { Inaccurate timing of } \\
\text { material order }\end{array}$ & 0,354 & 0,194 & 0,069 & Medium & Mitigation \\
\hline X7 & Delay of Equipment & 0,413 & 0,255 & 0,105 & Medium & Mitigation \\
\hline X8 & Equipment Damage & 0,421 & 0,228 & 0,096 & Medium & Mitigation \\
\hline X9 & Equipment Shortage & 0,433 & 0,229 & 0,099 & Medium & Mitigation \\
\hline
\end{tabular}




\begin{tabular}{|c|c|c|c|c|c|c|}
\hline Variable & Risks & $\begin{array}{l}\text { Frequency } \\
\text { (a) }\end{array}$ & $\begin{array}{l}\text { Impact } \\
\text { (b) }\end{array}$ & $\begin{array}{l}\text { Level of } \\
\text { Risk } \\
\text { Interest } \\
(\mathbf{a x b}) \\
\end{array}$ & $\begin{array}{c}\text { Risk } \\
\text { Category }\end{array}$ & $\begin{array}{c}\text { Risk } \\
\text { Handling } \\
\text { Strategy }\end{array}$ \\
\hline \multicolumn{7}{|c|}{ Design } \\
\hline $\mathrm{X} 10$ & $\begin{array}{l}\text { Error in Design by } \\
\text { Planner }\end{array}$ & 0,371 & 0,334 & 0,124 & Medium & Mitigation \\
\hline $\mathrm{X} 11$ & Design Changes & & & & & \\
\hline \multicolumn{7}{|c|}{ Human Resource } \\
\hline $\mathrm{X} 12$ & Less professional & 0,342 & 0,206 & 0,070 & Medium & Mitigation \\
\hline $\mathrm{X} 13$ & Less labor & 0,371 & 0,199 & 0,074 & Medium & Mitigation \\
\hline $\mathrm{X} 14$ & Low labor ability & 0,342 & 0,195 & 0,067 & Medium & Mitigation \\
\hline \multicolumn{7}{|c|}{ Finance } \\
\hline $\mathrm{X} 15$ & Inflation & 0,225 & 0,186 & 0,042 & Low & Monitoring \\
\hline $\mathrm{X} 16$ & $\begin{array}{l}\text { Financial Failure of the } \\
\text { Contractor }\end{array}$ & 0,238 & 0,271 & 0,064 & Medium & Mitigation \\
\hline $\mathrm{X} 17$ & $\begin{array}{l}\text { Poor Estimation of } \\
\text { Unexpected Cost }\end{array}$ & 0,379 & 0,175 & 0,066 & Medium & Mitigation \\
\hline $\mathrm{X} 18$ & $\begin{array}{l}\text { Incomplete Cost } \\
\text { Estimation }\end{array}$ & 0,358 & 0,175 & 0,063 & Medium & Mitigation \\
\hline X19 & Late Payment & 0,433 & 0,225 & 0,098 & Medium & Mitigation \\
\hline \multicolumn{7}{|c|}{ Management } \\
\hline $\mathrm{X} 20$ & $\begin{array}{l}\text { Error in Understanding } \\
\text { Contract Document }\end{array}$ & 0,233 & 0,193 & 0,045 & Low & Monitoring \\
\hline $\mathrm{X} 21$ & Document is incomplete & 0,350 & 0,184 & 0,065 & Medium & Mitigation \\
\hline $\mathrm{X} 22$ & Less coordination & 0,400 & 0,229 & 0,092 & Medium & Mitigation \\
\hline $\mathrm{X} 23$ & Dispute & 0,350 & 0,185 & 0,065 & Medium & Mitigation \\
\hline $\mathrm{X} 24$ & $\begin{array}{l}\text { Inadequate project } \\
\text { information (soil test and } \\
\text { survey report) }\end{array}$ & 0,325 & 0,249 & 0,081 & Medium & Mitigation \\
\hline $\mathrm{X} 25$ & $\begin{array}{l}\text { Error in choosing } \\
\text { implementation method }\end{array}$ & 0,375 & 0,252 & 0,095 & Medium & Mitigation \\
\hline $\mathrm{X} 26$ & $\begin{array}{l}\text { Less precise in applying } \\
\text { the method of } \\
\text { implementation }\end{array}$ & 0,358 & 0,274 & 0,098 & Medium & Mitigation \\
\hline $\mathrm{X} 27$ & Poor program scheduling & 0,400 & 0,206 & 0,083 & Medium & Mitigation \\
\hline $\mathrm{X} 28$ & $\begin{array}{l}\text { Many work errors require } \\
\text { rework }\end{array}$ & 0,346 & 0,255 & 0,088 & Medium & Mitigation \\
\hline $\mathrm{X} 29$ & $\begin{array}{l}\text { Job implementation does } \\
\text { not follow SOP }\end{array}$ & 0,354 & 0,297 & 0,105 & Medium & Mitigation \\
\hline $\mathrm{X} 30$ & Bad K3 management & 0,296 & 0,300 & 0,089 & Medium & Mitigation \\
\hline $\mathrm{X} 31$ & Subcontractor failure & 0,363 & 0,272 & 0,099 & Medium & Mitigation \\
\hline \multicolumn{7}{|c|}{ Nature and Environment Condition } \\
\hline $\mathrm{X} 32$ & Landslide & 0,363 & 0,327 & 0,119 & Medium & Mitigation \\
\hline $\mathrm{X} 33$ & Bad weather & 0,617 & 0,354 & 0,218 & High & Avoiding \\
\hline X34 & Late permissions & 0,421 & 0,220 & 0,092 & Medium & Mitigation \\
\hline
\end{tabular}




\begin{tabular}{|c|l|c|c|c|c|c|}
\hline Variable & \multicolumn{1}{|c|}{ Risks } & $\begin{array}{c}\text { Frequency } \\
\text { (a) }\end{array}$ & $\begin{array}{c}\text { Impact } \\
\text { (b) }\end{array}$ & $\begin{array}{c}\text { Level of } \\
\text { Risk } \\
\text { Interest } \\
\text { (axb) }\end{array}$ & $\begin{array}{c}\text { Risk } \\
\text { Category }\end{array}$ & $\begin{array}{c}\text { Risk } \\
\text { Handling } \\
\text { Strategy }\end{array}$ \\
\hline X35 & $\begin{array}{l}\text { A less secure project } \\
\text { development } \\
\text { environment }\end{array}$ & 0,358 & 0,238 & 0,085 & Medium & Mitigation \\
\hline X36 & $\begin{array}{l}\text { Disagreement interests } \\
\text { with citizens }\end{array}$ & 0,479 & 0,248 & 0,119 & Medium & Mitigation \\
\hline X37 & $\begin{array}{l}\text { Unstable government } \\
\text { policy }\end{array}$ & 0,304 & 0,218 & 0,066 & Medium & Mitigation \\
\hline
\end{tabular}

Based on the analysis that has been done and presented in table 4, there are 1 (one) risk in high category that is bad weather risk with avoidance strategy, 32 risks in medium category with mitigation handling strategy and 3 (three) low category risk which are material error in form, function and specification, the risk of inflation and the risk of error in the understanding of contract documents with monitoring strategies.

Bad weather is a risk with the highest level of risk interest in the high category, followed by the risk of error in design by the planner which belongs to the medium category. Bad weather is a risk caused by natural factors, so it is often unavoidable. But the fact is, not all jobs are affected by this bad weather. In other words on certain jobs, there are many solutions to overcome these risks. The risks to the project can be eliminated and can even be protected against the impact of the bad weather. So in certain circumstances, this risk is categorized as a risk that can be avoided.

Bad weather risk causes the work to be stopped temporarily. Another impact is also the difficult transportation to enter the project site because the road becomes muddy and slippery. Handling efforts as short-term avoidance response strategies are addition of shift workers to pay back wasted work time. Regarding jobs which are not too dangerous and not at altitudes such as processing iron activity, it will be overcome by the installation of tents during the absence of strong winds. The addition of additives substance to accelerate the process of concrete maturation, supported by the use of non-conventional formwork which can be assembled and unloaded faster to pursue delay in progress of work. While the longterm avoidance response strategy are evaluation and rearrangement the work schedule considering the weather forecast report issued by Badan Meteorologi, Klimatologi, Geofisika (BMKG), so jobs affected by these risks such as casting work, girder beam installation etc. can be scheduled on a good weather. Despite being the highest risk, in fact this risk is a seasonal risk, because it only happens when the rainy season comes.

Another high-level risk is a design error by planners that impact on construction failures. A short-term mitigation response strategy is to find an independent expert design to conduct an evaluation. The project team evaluates and then discusses with the design engineering consultant to revise the design. A long-term mitigation response strategy is to conduct periodic coordination and review with design engineering consultant.

\section{Conclusions and Suggestion}

The results of the analysis can be drawn the following conclusions: There are 36 risks that affect the bridge construction procurement project. Obtained 1 (one) high category risk that is bad weather risk, 32 moderate category risk and 3 (three) low category risk that is material mistake on form, function and specification, inflation and error occurred in the understanding of contract documents. The risk of bad weather is the greatest risk and the seasonal risk, the handling effort are 2 (two) avoidance response strategies. Short-term response strategies are addition of shift workers to pay back wasted work time to replace the 
wasted work time, installaion of tents for work that is not at altitude, addition of additives substance to accelerate the process of concrete maturation supported by the use of nonconventional formwork. Long-term response strategy are evaluation and rearrangement the whole of project schedule by considering the weather forecast report issued by BMKG.

This research is conducted on a bridge project along a defined toll road project and does not classify on certain types of bridges. Therefore, it is advisable to conduct research related to risk analysis with more specific bridge classification.

\section{References}

1. Taufik, H.A.R.M, Pengelolaan Risiko Kualitas pada Tahap Pelaksanaan Konstruksi di Lingkungan PT. X, Tesis Universitas Indonesia, Indonesia, (2010)

2. Choudhry, R.M., and Aslam, M.A., Risk Analysis of Bridge Construction Projects in Pakistan, Proceedings of International Council for Research and Innovation in Building and Construction (CIB) Working Commission W99. Purdue University, (2011)

3. Dziadosz, A., and Rejment, M, Risk Analysis in Construction Project - Chosen Methods, Procedia Engineering 122, pp: 258-265, (2015)

4. C.S. Pawar, S.S. Jain, J.R. Patil, IJIRAE, 2, 172-176, (2015)

5. A. Nurdiana, M.A. Wibowo, J.U.D. Hatmoko, Procedia Engineering, 125, 12-17 (2015)

6. International Standard, ISO 13000, (2009)

7. D. Hillson, Proceeding of, The Project Management Institute Annual Seminars \& Symposium, (2002)

8. Asmarantaka, N.S., Analisis Resiko yang Berpengaruh Terhadap Kinerja Proyek pada Pembangunan Hotel Batiqa Palembang, Jurnal Teknik Sipil dan Lingkungan, Vol. 2, no. 3, pp. 483-491A. Dziadosz, M. Rejment, Procedia Engineering, 122, 258-265 (2015)

9. Winaktu, G., Mulyadi, L., and Hargono, E., Penentuan Skala Prioritas Risiko pada Pembangunan Jembatan Afiat Desa Kanigoro Kecamatan Pagelaran Kabupaten Malang, Jurnal Info Manajemen Proyek, pp. 11-19 (2014)

10. Vidivelli, B., Vidhyasagar, E., and Jayasudha, K, Risk Analysis in Bridge Construction Projects, International Journal of Innovative Research in Science, Engineering and Technology, Vol. 6 no. 5, pp 8271-8284 (2017)

11. Zou, P.X.W., Zhang, G., and Wang, J.Y, Indentifying Key Risk in Construction Projects: Life Cycle and Stakeholder Perspectives, Proceedings of the 12th Pacific Rim Real Estate Society Conference, Auckland, New Zealand, (2006)

12. Project Management Institute, $A$ Guide to the Project Management Body of Knowledge, Fifth Edition PMBOK. Project Management Institute, Inc. Pennsylvania, (2013) 